\author{
Andrzej WINNICKI ${ }^{1}$ \\ Szymon SEREGA ${ }^{2}$ \\ Filip NORYS ${ }^{3}$
}

\title{
MODELOWANIE EFEKTÓW REAKCJI ASR - PRZYPADEK ZAPORY TYPU GRAWITACYJNEGO
}

\begin{abstract}
$\mathrm{W}$ artykule przedstawiono zagadnienie pełzania betonu sprzężone z reakcją alkalia-krzemionka (ASR). W pierwszej części zaprezentowano opis kinetyki reakcji, następnie omówiono model pełzania bazujący na podejściu normy Model Code 2010. Formuła analityczna jądra pełzania zapisana w Model Code 2010 została przedstawiona w postaci szeregowego połączenia prostych modeli reologicznych Kelvina. Wykonane testy numeryczne pokazały bardzo dobrą zgodność wyników na poziomie punktu materialnego. W kolejnej części przypomniano opracowany wcześniej przez autorów algorytm numeryczny do rozwiązywania problemów chemomechanicznych. Przeprowadzone przykładowe obliczenia dla zapory grawitacyjnej jasno pokazują, że wpływ pełzania na zachowanie się konstrukcji zapory jest stosunkowo niewielki w porównaniu do efektów spowodowanych przez reakcję alkalia-krzemionka.
\end{abstract}

Słowa kluczowe:ASR, reakcja alkalia-kruszywo, pełzanie betonu, betonowe konstrukcje hydrotechniczne

\section{Wprowadzenie}

Reakcja alkalia-krzemionka (ASR) w betonie jest obecnie dobrze rozpoznaną przyczyną uszkodzeń i postępującego pogorszenia stanu technicznego wielu konstrukcji betonowych oraz żelbetowych [4]. Zjawisko reakcji zostało po raz pierwszy zaobserwowane w 1940 roku przez Stantona, który badał przyczyny zarysowania konstrukcji żelbetowych w Kaliforni [4]. Stanton zasugerował, że przyczyną uszkodzeń betonu jest reakcja zachodząca w obecności wody pomiędzy alkaliami zawartymi w cemencie $\left(\mathrm{Na}_{2} \mathrm{O}, \mathrm{K}_{2} \mathrm{O}\right)$ oraz krzemionką $\left(\mathrm{SiO}_{2}\right)$ stanowiącą składnik kruszywa. Końcowym produktem reakcji jest hydrofilny żel silnie zwiększający objętość pod wpływem absorbcji wody.

\footnotetext{
${ }^{1}$ Autor do korespondencji/corresponding author: Andrzej Winnicki, Politechnika Krakowska, 31-155 Kraków, 1262823 73, andrzej@hypatia.L5.pk.edu.pl

${ }^{2}$ Szymon Seręga, Politechnika Krakowska, 31-155 Kraków, 1262823 96, szymon.serega@pk.edu.pl

${ }^{3}$ Filip Norys, Studia Doktoranckie Politechniki Krakowskiej, 31-155 Kraków, 1262823 73, filipnorys@interia.pl
} 
W ostatnich dwóch dekadach prowadzono liczne badania odnośnie chemomechanicznych aspektów reakcji ASR oraz wpływu produktów reakcji na zachowanie i trwałość istniejących konstrukcji betonowych. W rezultacie tych badań rozwinięto szereg chemomechanicznych modeli fenomenologicznych opisujących zachowanie się betonu poddanego oddziaływaniu reakcji ASR w różnych warunkach termicznych i wilgotnościowych - zob. np. [6-9].

Artykuł jest kontynuacją badań nad modelowaniem numerycznym oddziaływania reakcji alkalia-krzemionka, których wyniki były wcześniej prezentowane w pracach [10-11]. Obecnie skupiono się na wpływie pełzania sprzężonego $\mathrm{z}$ oddziaływaniem ASR.

\section{Opis kinetyki reakcji}

Opierając się na podejściu zaproponowanym w pracach [6]i[8] kinetyka reakcji jest definiowana za pomocą bezwymiarowej zmiennej zwanej stopniem reakcji $\xi$, opisującej rozwój reakcji, zmieniającej się od 0.0 do 1.0 . W przypadku reakcji ASR, charakteryzującej się przyrostem objętości produktu w stosunku do składników (pęcznieniem), stopień reakcji jest funkcją chemicznego odkształcenia objętościowego spowodowanego reakcją i opisuje się równaniem:

$$
\xi(t)=\frac{\varepsilon_{A S R}(t)}{\varepsilon_{A S R}^{\infty}} \quad, \quad \varepsilon_{A S R}^{\infty}=\varepsilon_{A S R}(t \rightarrow \infty), \quad 0.0 \leq \xi(t) \leq 1.0
$$

w którym $\varepsilon_{\text {ASR }}(t)$ jest swobodnym odkształceniem betonu w czasie $t$ powstałym w wyniku reakcji ASR, $\varepsilon_{A S R}^{\infty}$ jest maksymalnym, końcowym swobodnym odkształceniem betonu spowodowanym reakcją ASR. W ten sposób wewnętrzna zmienna $\xi$ jest stowarzyszona z mierzalną wielkością - swobodnym odkształceniem betonu. Kinetyka reakcji opisana jest następującym równaniem:

$$
A_{m}(\xi)=k_{d} \frac{d \xi}{d t}
$$

gdzie $A_{m}(\xi)$ jest zmianą w stężeniu molowym substratów, $k_{d}$ jest parametrem reakcji. Wartość $A_{m}(\xi)$ zmniejsza się od wartości na początku reakcji wynoszącej $A_{m}(\xi=0.0)=A_{m 0}$ do wartości końcowej $A_{m}(\xi=1.0)=0.0$ kiedy reakcja zanika. Rząd kinetyki reakcji jest określony poprzez funkcję $A_{m}(\xi)$. Na podstawie pracy [5]przyjęto zmodyfikowaną postać kinetyki reakcji pierwszego rzędu:

$$
1-\xi=t_{c}(\xi) \frac{d \xi}{d t}
$$


Powyższa relacja nie opisuje wprost kinetyki pierwszego rzędu ponieważ parametr $t_{c}$ zależy od stopnia reakcji według następującej formuły:

$$
t_{c}(\xi)=\tau_{c h} \frac{1+\exp \left(-\tau_{\text {lat }} / \tau_{c h}\right)}{\xi+\exp \left(-\tau_{\text {lat }} / \tau_{c h}\right)}
$$

gdzie $\tau_{\text {lat }}$ jest czasem opóźnienia (opisującym pierwszy okres reakcji, podczas którego żel wypełnia pory betonu wywierając niewielkie ciśnienie na szkielet materiału), $\tau_{c h}$ jest czasem charakterystycznym, od którego zależy prędkość reakcji. W przypadku stałych w czasie temperatury i wilgotności (tzn. $\tau_{\text {lat }}$ oraz $\tau_{c h}$ mają stałą wartość) równanie (1) ma rozwiązanie zamknięte:

$$
\xi(t, T)=\frac{1-\exp \left(-t / \tau_{c h}(T)\right)}{1+\exp \left(-\left(t-\tau_{\text {lat }}(T)\right) / \tau_{c h}(T)\right)}
$$

W pracy [5] zaproponowano zależność powyższych stałych od temperatury wykorzystując prawo Arrheniusa:

$$
\tau_{\text {lat }}(T)=\tau_{\text {lat }}\left(T_{0}\right) \exp \left(U_{\text {lat }}\left(\frac{1}{T}-\frac{1}{T_{0}}\right)\right) ; \tau_{c h}(T)=\tau_{c h}\left(T_{0}\right) \exp \left(U_{c h}\left(\frac{1}{T}-\frac{1}{T_{0}}\right)\right)
$$

gdzie $U_{l a t}$ i $U_{c h}$ są termicznymi stałymi aktywacji odpowiednio dla czasu opóźnienia $\tau_{\text {lat }}$ i czasu charakterystycznego $\tau_{c h}$. W celu uwzględnienia wpływu wilgotności względnej na rozwój reakcji autorzy niniejszej pracy zmodyfikowali powyższe formuły:

$$
\begin{aligned}
& \tau_{\text {lat }}(T, R H)=\tau_{\text {lat }}\left(T_{0}\right) \exp \left(U_{\text {lat }}\left(\frac{1}{T}-\frac{1}{T_{0}}\right)\right) f_{5}(R H) \\
& \tau_{c h}(T, R H)=\tau_{c h}\left(T_{0}\right) \exp \left(U_{c h}\left(\frac{1}{T}-\frac{1}{T_{0}}\right)\right) f_{6}(R H)
\end{aligned}
$$

gdzie $f_{5,6}(R H)=\left(\frac{R H}{100}\right)^{k, l}$.

W powyższych równaniach zostały wprowadzone dodatkowe parametry $k$ oraz $l$. Opracowana została procedura kalibracji parametrów modelu na podstawie danych doświadczalnych (zarówno zaproponowanych w pracy [5] jak i nowo wprowadzonych), wykorzystująca metodę najmniejszych kwadratów. Szczegółowa analiza oraz porównanie symulacji numerycznych z dostępnymi rezultatami doświadczeń ([5], [7]) została przedstawiona w pracach [10-11]. W opinii autorów wyniki obliczeń bardzo dobrze odzwierciedlają rezultaty eksperymentów. 


\section{Model petzania betonu}

Nowym elementem w proponowanym podejściu do symulacji oddziaływania reakcji ASR na konstrukcje betonowe jest uwzględnienie zjawiska pełzania betonu. Ze względu na fakt, że czas rozwoju reakcji ASR jest długi (w rzeczywistych obiektach wynoszący kilka do kilkudziesięciu lat) analiza mechaniczna powinna uwzględniać efekty pełzania betonu. W artykule przyjęto analityczny model pełzania według normy Model Code 2010 [15]. W normie tej współczynnik pełzania został rozdzielony na dwie składowe: pełzanie bazowe oraz pełzanie $\mathrm{w}$ wyniku wysychania betonu. W artykule analizowane są konstrukcje masywne (zapory grawitacyjne), w przypadku których zmiany wilgotności praktycznie w całej konstrukcji są niewielkie. Dlatego bez popełniania większego błędu składową pełzania od wysychania można zaniedbać. Ponadto w modelu pełzania jest niezbędnym uwzględnienie wpływu stopnia reakcji ASR. W proponowanym podejściu przyjęto, że jedynie moduł sprężystości jest funkcją stopnia reakcji $\xi$. Sprzężenie pomiędzy stopniem reakcji ASR (powodującym redukcję modułu sprężystości), a pełzaniem betonu zostało uwzględnione w następujący sposób:

$$
J(t, \tau, \xi)=\frac{1}{E_{0}(\xi)}+\frac{\varphi_{b c}(t, \tau)}{E_{0}(\xi=0.0)}
$$

gdzie $J(t, \tau, \xi)$ jest jądrem pełzania, $E_{0}$ jest modułem sprężystości betonu, $\varphi_{b c}$ jest bazowym współczynnikiem pełzania wg [15]. Na rys. 1a przedstawiono przykładowe przebiegi funkcji pełzania $J$ dla różnych czasów obciążenia konstrukcji oraz stopnia reakcji $\xi=0.0$.

$\mathrm{W}$ analizie numerycznej funkcja pełzania jest aproksymowana za pomocą skończonego szeregu Dirichleta. Zdegenerowana formuła na funkcję pełzania może być interpretowana jako szeregowe połączenie kilku klasycznych modeli Kelvina (szeregowy układ $n$ zestawów równolegle połączonych tłumika wiskotycznego i sprężyny):

$$
\bar{J}(t, \tau, \xi)=\frac{1}{E_{0}(\xi)}+\sum_{i=1}^{n} \frac{1}{E_{i}(\tau)}\left(1-e^{-\frac{t-\tau}{\lambda_{i}}}\right)
$$

gdzie $E_{i}$ są sztywnościami poszczególnych sprężyn w modelu szeregowym, a $\lambda_{i}$ czasami opóźnienia (retardacji). Zdegenerowana formuła (3), opisująca funkcję pełzania, pozwala w procesie obliczeniowym uniknąć konieczności pamiętania pełnej historii naprężenia $\sigma(t)$. Powyższy model jest standardowo zaimplementowany w programie DIANA [14].Sztywności $E_{i}$ potrzebne do zdefiniowania zdegenerowanej funkcji pełzania dla wybranych czasów opóźnienia $\lambda_{i}$ zostały wyliczone wykorzystując procedury kalibracji parametrów materiało- 
wych dostępnych w programie DIANA przy ograniczeniu szeregu modeli Kelvina do trzech elementów $(n=3)$. Obliczenia kalibracyjne wykonano dla zerowej wartości kinetyki reakcji. Wartości sztywności $E_{i}$ oraz czasy retardacji zostały pokazane na rys. $1 \mathrm{~b}$.

a)

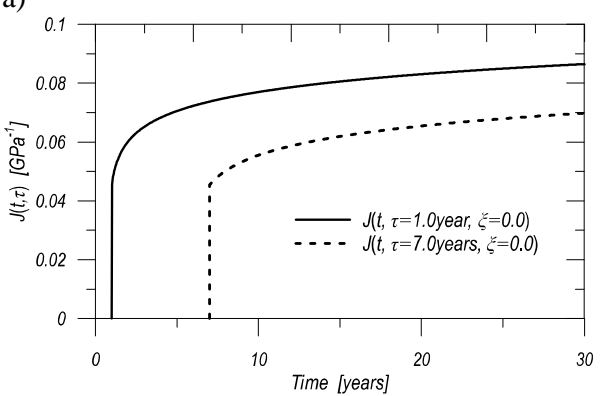

b)

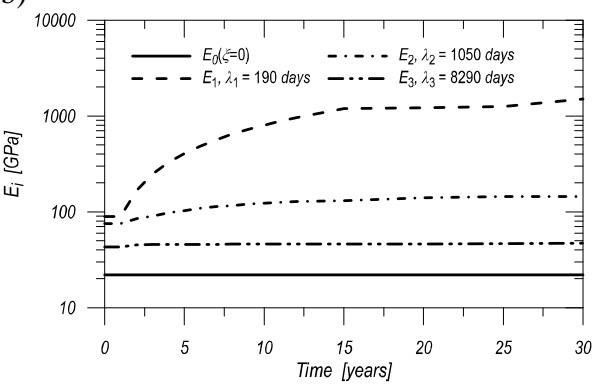

Rys. 1. a) przykładowe funkcje pełzania analizowanej zapory, b) parametry materiałowe zdegenerowanego modelu funkcji pełzania

Fig. 1. a) example of creep functions for concrete in analyzed dam, b) materials parameters for degenerated model of creep function

W celu porównania odpowiedzi mechanicznej materiału otrzymanej na podstawie funkcji pełzania wg [15] i jej zdegenerowanej formy wykonano przykładowe obliczenia na poziomie punktu materialnego. Dla podejścia [15] zaimplementowano stosowną procedurę całkowania równań fizycznych w programie MathCAD, natomiast dla zdegenerowanej funkcji pełzania użyto modelu materiału dostępnego w bibliotece materiałów programu DIANA. W obliczeniach uwzględniono zmienny w czasie przebieg stopnia reakcji $\xi$, zdefiniowany jako wartość wejściowa.

Na rys. 2 pokazano dwa analizowane scenariusze obciążenia oraz przebieg reakcji w czasie. Pierwszy schemat obciążenia jest funkcją okresowo stałą, drugi scenariusz obciążenia przebiega zgodnie z funkcją sinus, natomiast stopień reakcji

a)

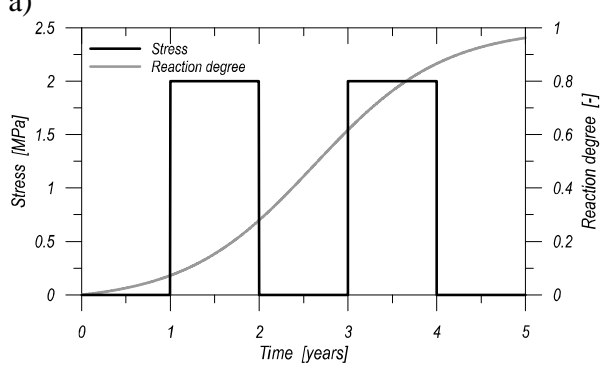

b)

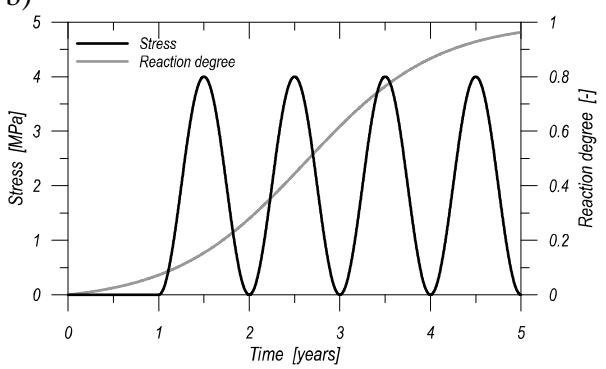

Rys. 2. Scenariusze obciążeń oraz przebieg reakcji ASR w czasie

Fig. 2. Loading scenarios and ASR reaction course in time 
przebiega od 0.0 do 1.0. W analizowanych przypadkach obciążenia odpowiedź materiału wskazuje, że formuła zdegenerowana funkcji pełzania dostarcza wyniki o dużej zgodności z rozwiązaniem analitycznym dla funkcji pełzania danej w [15] - rys.3.

a)

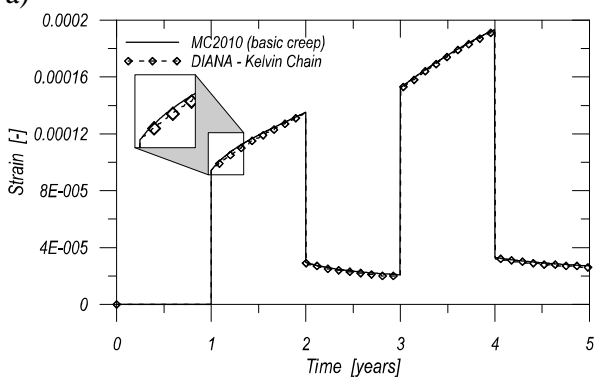

b)

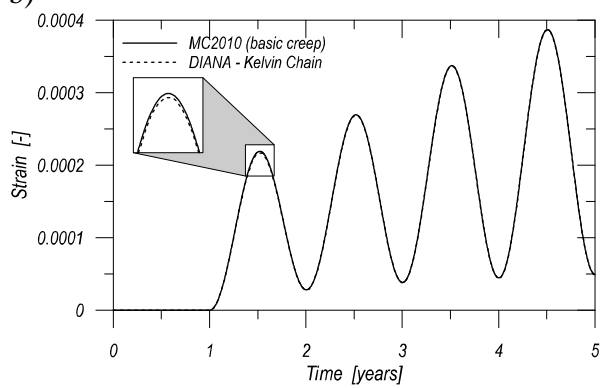

Rys. 3. Odkształenia pełzania obliczone dla funkcji pełzania według równań (2) i (3)

Fig. 3. Calculated strains for creep functions according to Eq. (2) and (3)

\section{Algorytm numeryczny}

Autorzy opracowali algorytm numeryczny dla zaprezentowanej w punkcie 2 kinetyki reakcji pozwalający, na modelowanie problemów chemomechanicznych z wykorzystaniem standardowych programów do nieliniowej analizy MES (np. DIANA) - [10-11]. Algorytm ten jest przytoczony jeszcze raz poniżej ze względu czytelność i kompletność niniejszej pracy.

Stopień reakcji jest traktowany jako zmienna wejściowa (zmienna stanu) do analizy mechanicznej. Dlatego dla danych warunków początkowych i zmiennych w czasie warunków brzegowych, stopień reakcji $\xi$ jest obliczany jako zmienna skalarna na danym obszarze dla każdej chwili czasowej.

Ponieważ stopień reakcji silnie zależy od temperatury i wilgotności względnej najpierw należy obliczyć pola tych zmiennych w całym analizowanym przedziale czasowym. $\mathrm{W}$ prezentowanym podejściu pola termiczne $\mathrm{i}$ wilgotnościowe potraktowano jako rozprzężone, a zmienne w czasie temperaturę i wilgotność względną obliczono rozwiązując niestacjonarne równanie FourieraKirchhoffa dla problemu termicznego i równanie transportu masy w przypadków pól RH [12].Zależne od wilgotności parametry materiałowe takie jak izotermy sorpcji, pojemność wilgotności oraz dyfuzyjność betonu, niezbędne do rozwiązania równania transportu masy (wilgoci), zostały zaczerpnięte z pracy [13]. Współczynnik przewodzenia ciepła oraz pojemność cieplną betonu przyjęto stałe. Powyższe obliczenia wykonano z wykorzystaniem standardowych modeli transportu potencjału zaimplementowanych w systemie MES DIANA. Schematyczne podsumowanie wstępnej analizy termiczno- wilgotnościowej przedstawiono na rys. 4. 


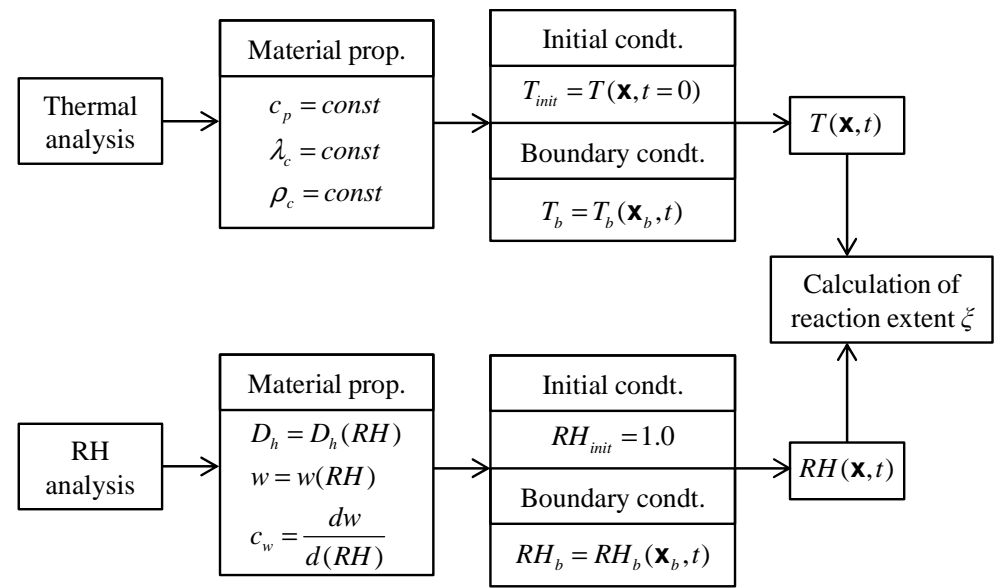

Rys. 4 Algorytm obliczeniowy - część 1

Fig. 4. Computationalalgorithm - part-1

Mając dane wyjściowe pola termiczne i wilgotnościowe w całym analizowanym przedziale czasowym oblicza się niestacjonarne pole stopnia reakcji $\xi$ rozwiązując równanie (1) - rys. 5a. W ostatnim stadium obliczeniowym przeprowadza się analizę mechaniczną z wykorzystaniem pola $\xi$ jako zmiennej wejściowej - rys. $5 b$.

W analizie mechanicznej przyjęto, że zarówno moduł sprężystości oraz parametry wytrzymałościowe (wytrzymałość na rozciąganie, energia pękania) są

a)

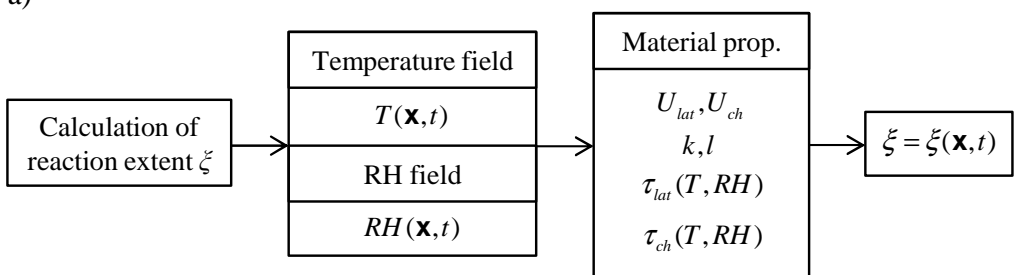

b)

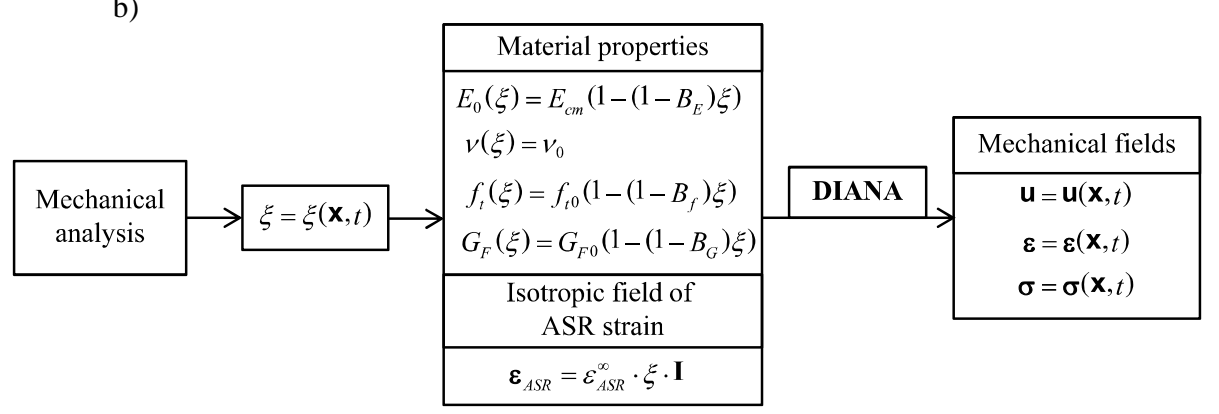

Rys. 5 Algorytm obliczeniowy - część 2

Fig. 5. Computationalalgorithm - part-2 
funkcjami zależnymi od stopnia reakcji $\xi$ oraz że ulegają degradacji wraz ze wzrostem wartości $\xi$. Pęcznienie betonu w wyniku reakcji ASR zostało uwzględnione jako izotropowe, wymuszone odkształcenie chemiczne $\varepsilon_{A S R}$ liniowo zależne od zmiennej $\xi$. Beton został zamodelowany z wykorzystaniem podejścia wielokierunkowych, nieortogonalnych rys rozmytych [2] z uwzględnieniem pełzania w postaci modelu zdegenerowanego opisanego w punkcie 3 .

Szczegóły sprzężenia pomiędzy modelem rys rozmytych i pełzania opisano w pracy [3]. Obiektywność rozwiązania względem przyjętych wymiarów siatki elementów skończonych uzyskano poprzez utrzymanie stałej energii pękania dla powierzchni „zarysowanego” elementu skończonego (jest to tzw. podejście „fractureenergy trick” [2]).

\section{Przykład analizy zapory}

Jako przykład ilustrujący prezentowane podejście do modelowania wpływu reakcji ASR na rzeczywiste konstrukcje betonowe wybrano przypadek zapory grawitacyjnej Fontana, analizowanej również przez innych badaczy [1]. Zapora Fontana zlokalizowana jest w Północnej Karolinie w Stanach Zjednoczonych Ameryki Północnej, w hrabstwie Graham. Budowa obiektu została ukończona w 1946 roku. Trzy lata później zaobserwowano pierwsze zarysowania konstrukcji wraz z przemieszczeniem korony w stronę zbiornika. Kolejne przeglądy (rok 1972) wykazały duże pęknięcia wewnątrz zapory. Badania petrograficzne z 1999 roku wykazały w betonie obecność produktów reakcji ASR [1].

Na rysunku 6 przedstawiono analizowaną zaporę wraz z podłożem, zastosowaną topologią siatki MES oraz warunkami brzegowymi i początkowymi. W poprzednich pracach zespołu autorskiego [10-11] zaprezentowano analizę niniejszej zapory poddanej obciążeniu ciężarem własnym, obciążeniu hydrostatycznemu wody oraz oddziaływaniu reakcji ASR, ale bez uwzględnienia odkształceń pełzania. Obecnie, w nawiązaniu do poprzednich wyników, analizowany jest identyczny obiekt, $\mathrm{z}$ tym, że w obliczeniach uwzględniono wpływ pełzania. Szczegóły parametrów mechanicznych i chemicznych modelu, jak również dokładny opis warunków brzegowych dostępny jest w pracach [10-11].

Analiza numeryczna zapory Fontana składa się z dwóch części. Pierwsza jest odwzorowaniem normalnej eksploatacji konstrukcji w okresie 30-letnim, druga opisuje sytuację wyjątkową - powodziowe podwyższenie się zwierciadła wody ponad koronę zapory aż do zniszczenia konstrukcji.

Postępując według algorytmu streszczonego powyżej w pierwszym kroku analizy wyznaczono pola termiczne i pola wilgotności względnej w konstrukcji. Na podstawie tych pól obliczono pole stopnia reakcji w całym rozpatrywanym przedziale czasowym. Wyniki obliczeń po 7, 14 i 30 latach pokazano na rys. 7 .

Na rysunku 8 zaprezentowano morfologię zarysowania po 30 latach oddziaływania ASR z uwzględnieniem i bez uwzględnienia efektów pełzania. Rysunek ten pokazuje, że pełzanie zmniejsza obszary zarysowań głównie w środkowej części zapory. 


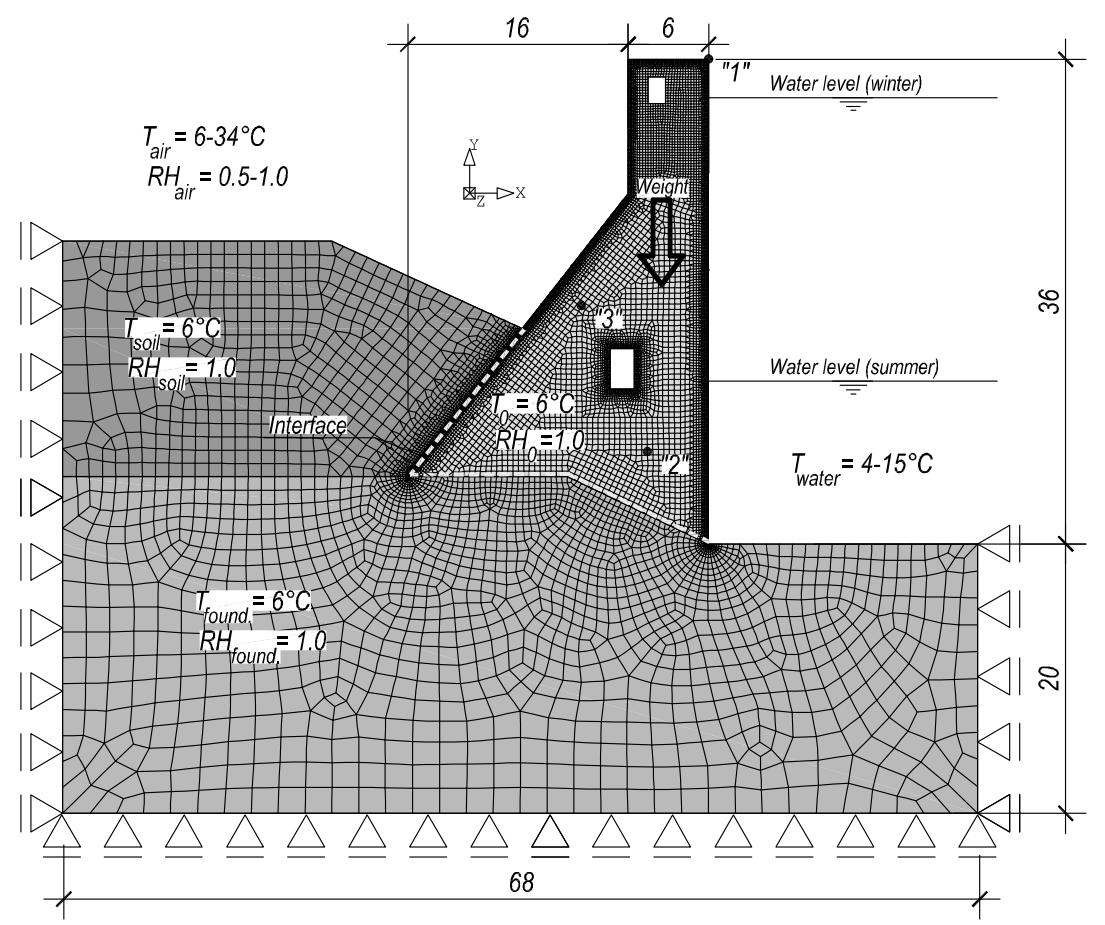

Rys. 6. Przekrój przez zaporę Fontana wraz z podłożem

Fig. 6. Cross section of Fontana dam together with foundation on subsoil
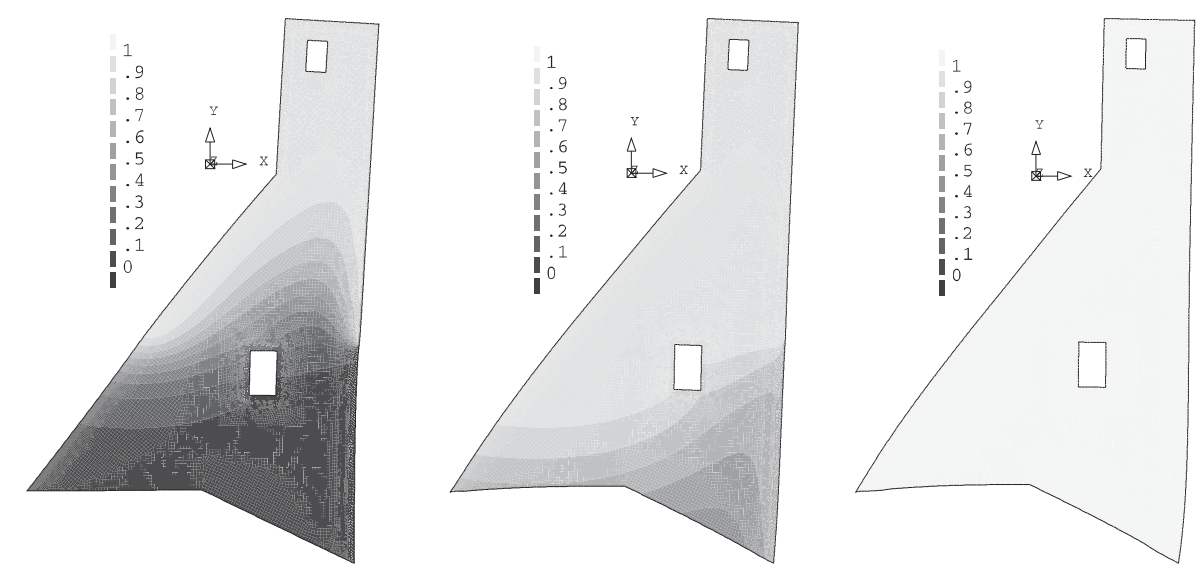

Rys. 7. Pola stopnia reakcji w konstrukcji zapory po 7, 14 i 30 latach

Fig. 7. Reaction extent fields in dam: after 7, 14 and 30 years, respectively 
a)

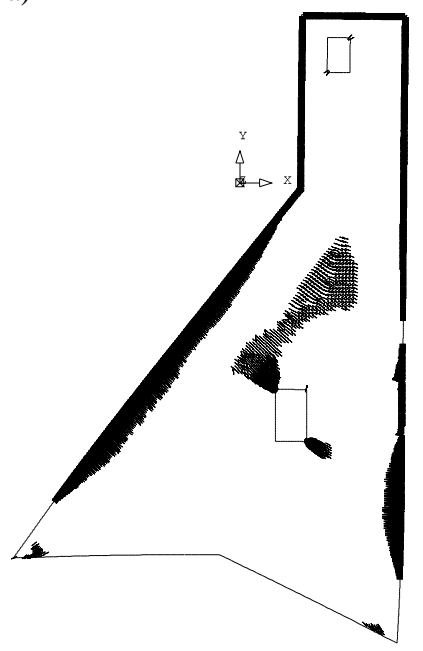

b)

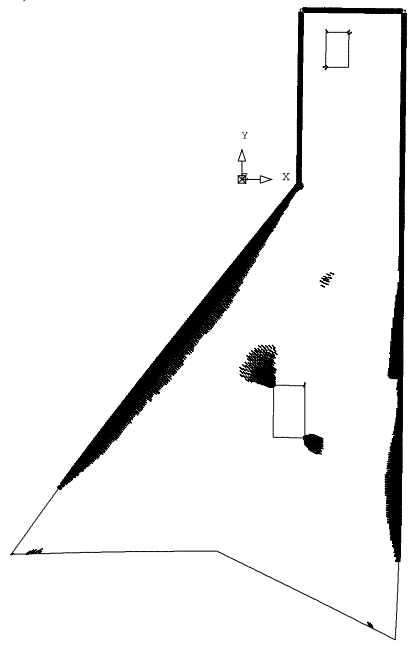

Rys. 8. Morfologia zarysowań po 30 latach, $\varepsilon_{A S R}^{\infty}=0.075 \%$ : a) bez pełzania, b) z pełzaniem (na rysunku pokazano również rysy zamknięte)

Fig. 8. Crack pattern after 30 years, $\varepsilon_{A S R}^{\infty}=0.075 \%$ : a) without creep, b) with creep (note that closed cracks are also shown)

Na rysunku 9 przedstawiono historię przemieszczeń korony zapory. Z rysunku tego wynika, że po 30 latach oddziaływania ASR przemieszczenia zapory są ustabilizowane. Ponadto z rysunku 9 można wnioskować, że wpływ pełzania na przemieszczenia konstrukcji jest zaniedbywalnie mały.

Następnym przypadkiem obliczeniowym jest sytuacja wyjątkowa - fala powodziowa oddziałująca na konstrukcję po 30 latach rozwoju reakcji ASR
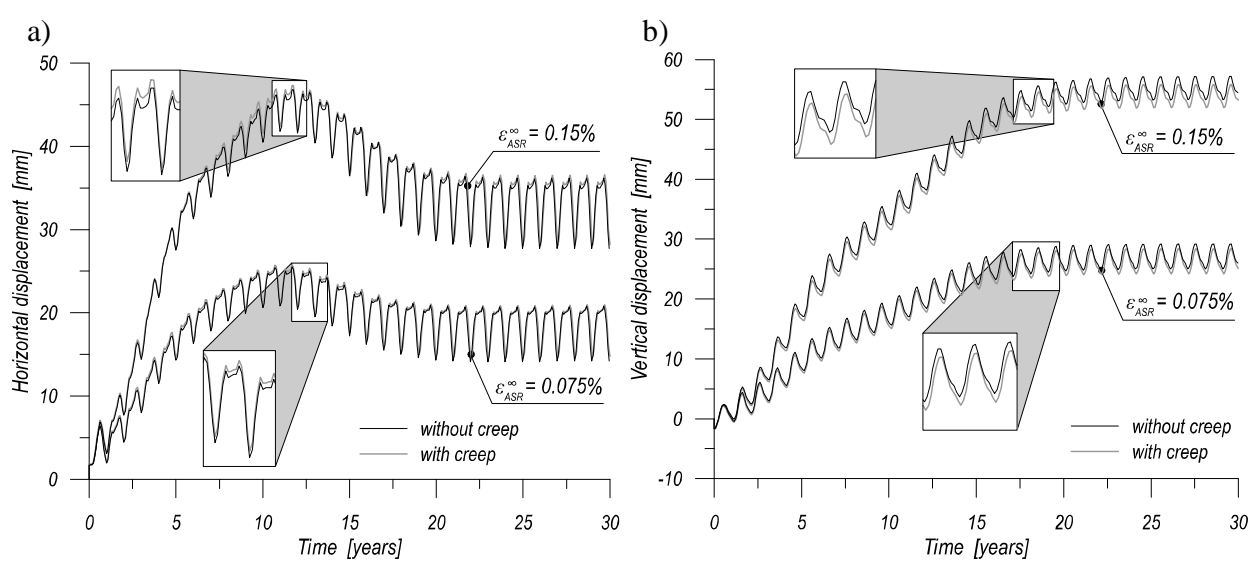

Rys. 9 Przemieszczenia korony zapory: a) poziome, b) pionowe

Fig. 9. Displacements of the crown of dam: a) horizontal, b) vertical 
wraz z uwzględnieniem odkształceń pełzania. Na rysunku 10 pokazano przemieszczenia korony zapory w stosunku do tzw. Współczynnika przewyższenia fali powodziowej (współczynnik ten definiowany jest jako stosunek wysokości zwierciadła wody podczas powodzi $H_{\text {wave }}$ do wysokości zapory $H_{d a m}$ ). Wartość $H_{\text {wave }} / H_{\text {dam }}$ należy interpretować jako globalny współczynnik bezpieczeństwa konstrukcji.

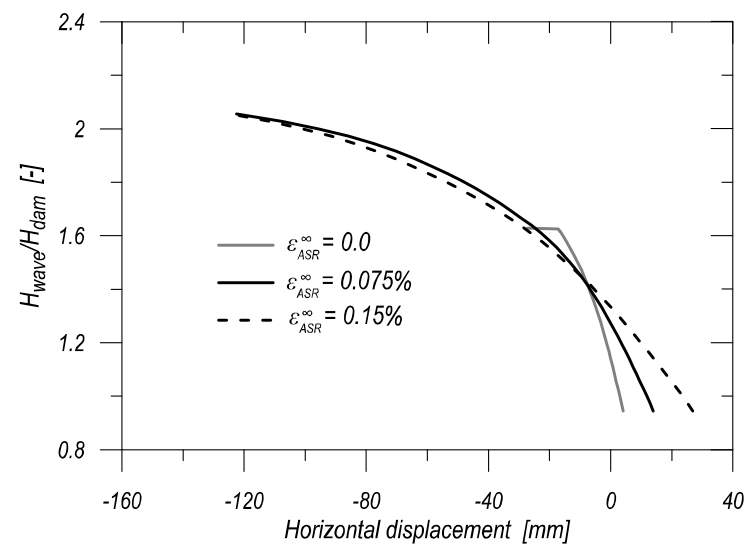

Rys. 10. Współczynnik przewyższenia fali powodziowej versus przemieszczenia poziome zapory

Fig. 10. Overtopping ratio versus horizontal displacement

Współczynnik $H_{\text {wave }} / H_{\text {dam }}$ obliczony po 30 latach oddziaływania ASR jest równy 2.1 - rys. 10. Na rysunku tym pokazano analogiczny wykres dla konstrukcji bez wpływu reakcji ASR. Okazuje się, że w tym przypadku współczynnik przewyższenia jest mniejszy niż dla konstrukcji z wpływem ASR. Tę kontrowersyjną obserwację można wytłumaczyć poprzez fakt, że odkształcenia chemiczne wprowadzają samorównoważący się stan naprężeń, które to naprężenia mają charakter ściskający od strony zbiornika wody, w obszarze przekroju krytycznego tuż powyżej galerii inspekcyjnej (efekt lokalnego doprężenia). $\mathrm{Z}$ tego rysunku można również wywnioskować, że konstrukcja zaatakowana reakcją ASR jest znacznie bardziej podatna w porównaniu z zaporą bez wpływu reakcji ASR. Zachowanie takie można wytłumaczyć dużą ilością uszkodzeń nagromadzonych w wyniku oddziaływania reakcji ASR na beton.

\section{Podsumowanie}

Artykuł jest kontynuacją prac nad modelowaniem numerycznym reakcji alkalia-kruszywo $\mathrm{w}$ betonie. Wyniki tych prac były wcześniej publikowane w pracach [10-11]. Obecnie skupiono się na analizie łącznego wpływu pełzania oraz reakcji ASR. Dla opisu pełzania wykorzystano podejście z [15] ze zdegenerowaną funkcją pełzania. Przeprowadzone testy numeryczne pokazują, że aprok- 
symacja funkcji pełzania $\mathrm{z}$ wykorzystaniem jedynie trzech szeregowo połączonych reologicznych modeli Kelvina wystarczająco dokładnie odzwierciedla formułę analityczną.

Efekty mechaniczne reakcji ASR w połączeniu z pełzaniem zostały obliczone $\mathrm{z}$ wykorzystaniem program DIANA stosując algorytm rozwiązywania problemów chemomechanicznych rozwijany przez autorów ([10-11]). Jako model mechaniczny wykorzystano zaimplementowany w programie DIANA klasyczny model wielokierunkowych rys rozmytych [2]. Sprzężenie pomiędzy pełzaniem i zarysowaniem uwzględniono wg pracy [3].

Jako przykład numeryczny wybrano przypadek zapory Fontana, który był wcześniej analizowany bez uwzględnienia pełzania [10-11]. Porównanie wyników z i bez pełzania wyraźnie wskazuje, że efekty lepkie mają charakter zaniedbywalny. Stąd płynie wniosek, że w przypadku modelowania oddziaływania reakcji ASR w betonowych konstrukcjach masywnych pominięcie wpływu pełzania jest akceptowalne i zwykle prowadzi do wyników po bezpiecznej stronie.

\section{Literatura}

[1] Comi, C., Fedele, R. and Perego, U.: A chemo-thermo-damage model for the analysis of concrete dams affected by alkali-silica reaction. Mech. Mat., 2009., 41:210-230.

[2] de Borst, R.: Smeared cracking, plasticity, creep and thermal loading - a unified approach. Com. Meth. Appl. Mech. Eng., 1987, 62:89-110.

[3] de Borst, R., and van den Boogaard, A. H.: Finite-element modeling of deformation and cracking in early-age concrete. J. Eng. Mech. Div.,1994, ASCE 120:2519-2534.

[4] Hobbs, D.W.: Alkali-silica reaction in concrete. Thomas Telford, London1988.

[5] Larive, C.: Apportscombinés de l'expérimentation et de la modélisation a la comprehension de l'alcali reaction et de seseffetsmécaniques. Technical Report LPC, OA 28, Laboratoires des Ponts et Chaussées, Paris 1998.

[6] Pietruszczak, S.: On the mechanical behaviour of concrete subjected to alkaliaggregate reaction. Computers \& Structures, 1996, 58:1093-1097.

[7] Poyet, S.: Etude de la dégradation des ouvragesenbétonatteintspar la réactionalcalisilice: Approcheexpérimentale et modélisationnumérique multi-échelles des dégradationsdans un environnement hydro-chemo-mécanique variable. $\mathrm{PhD}$ thesis, Universite de Marne-La-Valleé, 2003.

[8] Ulm, F.-J., Coussy O., Li, K., and Larive, C.: Thermo-chemomechanics of ASR expansion in concrete structures. J. of Eng. Mech.,2000, 126:233-242.

[9] Winnicki, A. andPietruszczak, S.: On mechanical degradation of reinforced concrete affected by alkali-aggregate reaction. J. Eng. Mech., 2008, 134:611-628.

[10] Winnicki, A., Seręga, S. and Norys, F.: Chemoplastic modelling of Alkali-Silica Reaction (ASR). Computational Modelling of Concrete Structures Euro-C 2014 Int. Conf., 765-774, St. Anton am Arlberg2014, Austria.

[11] Winnicki, A., Seręga, S. and Norys, F. Alkali-silica reaction in concrete - chemomechanical description. Cracow University of Technology Jubilee Monograph478, Kraków2015. 
[12] Xi, Y., Bažant, Z. P., and Hamlin, M. J.: Moisture diffusion in cementitious materials. Adsorption isotherms. Adv. Cem. Bas. Mater., 1994, 1:248-257.

[13] Xi, Y., Bažant, Z. P., and Hamlin, M. J.: Moisture diffusion in cementitious materials. Moisture capacity and diffusivity. Adv. Cem. Bas. Mater., 1994, 1:258-266.

[14] DIANA Finite Element Analysis. User's Manual.

[15] International Federation for Structural Concrete, fib Model Code 2010. Final Draft - Volume 1, Lausanne2012, Switzerland.

\section{MODELLING OF ASR REACTION EFFECTS - CASE STUDY OF GRAVITY DAM}

\section{S u m m a r y}

Paper deals with creep effects being combined with alkali-silica reaction (ASR) in concrete. At first description of reaction kinetics is discussed, then the creep model is presented based on Model Code 2010 approach. An approximation of analytical formulation in the form of Kelvin chain is proposed. Presented numerical examples show that it renders analytical formulation really well. Next a numerical algorithm developed previously by authors in order to solve chemomechanical problems is recalled. Performed exemplary numerical computations for a gravity dam show clearly that the influence of creep on the overall behavior of the structure is relatively small in comparison with effects caused by ASR itself.

Keywords: ASR, alkali-silica reaction, concrete creep, concrete hydrotechnical structures

Przestano do redakcji: 07.06.2016 $r$.

Przyjęto do druku: 30.06.2016 r.

DOI: 10.7862/rb.2016.60 
